\title{
РЕФЛЕКСИИ ЗА КАФКА И ПРАВОТО
}

\section{Славица Србиновска}

Универзитет „Св. Кирил и Методиј“, Скопје

slavicasrbinovska@flf.ukim.edu.mk

\section{Маја Бојаџиевска}

Универзитет „Св. Кирил и Методиј“, Скопје

maja.bojadjievska@flf.ukim.edu.mk

\section{Ирина Талевска}

Универзитет „Св. Кирил и Методиј“, Скопје irinatalevska@flf.ukim.edu.mk

Овој труд е резултат на истражувањата и рефлексиите што произлегоа од работилницата под наслов Франц Кафка: Оو „Колонија на казнейийе“ gо

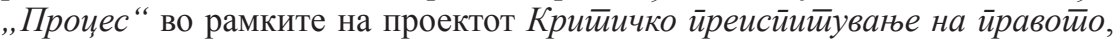
одржана на Правниот факултет „Јустинијан Први“. Во трудот е направена анализа на творештвото на Франц Кафка низ еден мошне специфичен ракурс во чии рамки книжевноста се поврзува со правото во својата филозофска димензија. Целта на овој труд е, врз основа на филозофските рефлексии на Теодор Адорно, Жил Делез и Феликс Гатари, како и филозофско-лингвистичкиот есеј на Џорџо Агамбен посветен на Кафка, да се даде придонес кон новите, свежи перспективи на толкувањето на делото на Кафка, кои го реактуализираат авторот во контекстот на сѐ подинамичните и комплексни текови на општествено-политичкиот поредок.

Клучни зборови: книжевна машина, закон, вина, казна, јазик 


\title{
SOME REFLECTIONS ON KAFKA AND THE LAW
}

\author{
Slavica Srbinovska
}

Ss. Cyril and Methodius University in Skopje

slavicasrbinovska@flf.ukim.edu.mk

Maja Bojadžievska

Ss. Cyril and Methodius University in Skopje

maja.bojadjievska@flf.ukim.edu.mk

Irina Talevska

Ss. Cyril and Methodius University in Skopje irinatalevska@flf.ukim.edu.mk

This paper is a follow-up to a research conducted for the purposes of the workshop entitled Franz Kafka: from the 'Penal Colony' to 'Process' held at Iustinianus Primus Faculty of Law as a part of the project Critical Re-Examination of Law. The paper encompasses an analysis of the works by Franz Kafka from a point of view that relates literature with the concept of Law. This paper draws on the philosophical reflections of Teodor Adorno, Giles Deleuse and Félix Guattari, as well as on Giorgio Agamben's philosophical paper dedicated to Kafka, and aims at offering new perspectives to the interpretation of Kafka's work which situate the writer the in the context of the contemporary dynamic tenndecies within the social and the political order.

Keywords: literary machine, law, guilt, punishment, language 
Og лаг̄и се г̄раяи ӣореоокой во свейой.

Франц Кафка, Проиес

\section{1 Книжевна машина}

Нарекувајќки го делото на Франц Кафка „книжевна машина“, во духот на сопственото поимање на уметноста како територија на перцепции и афекти, чија комбинација се реализира секогаш на различен начин, Делез и Гатари го актуализираат ова прашање за уметноста наспроти филозофијата и науката. Со поимот „книжевна машина“ го потиснуваат поимот „структура“. Врз основа на концепцијата за „книжевната машина“ се засновани настојувањата во кои се реализира толкувањето на делото на Кафка и неговиот однос или поврзаност со правото. Делез и Гатари настојуваат овој поим да го поистоветат со специфичностите на уметноста на ова дело. Поимот „книжевна машина“ произлегува од односот меѓу филозофијата и литературата, а често е заменуван и со ознаката „колективно искажување“, бидејќи е поим што во себе ги антиципира односите меѓу моќта, јазикот, општеството и желбата. Сферата на книжевноста низ перспективата на вака насочените филозофско-социолошки и психоаналитички концепции се поврзува со идејата за неа како „машина на желбите“. Низ оваа призма двајцата аналитичари ги изведуваат своите толкувања, а концептот за „литературната машина“ го развиваат, поконкретно, врз основа на делата на Франц Кафка, Семјуел Бекет и на Марсел Пруст. Цел во нивното форматирање на идејата е анализа на врската меѓу субјектот и јазикот на уметноста на пишувањето. Во прилог на оваа идеја ни се наложува да ги осмислиме и да ги поврземе традиционалните становишта на Теодор Адорно за „негативната дијалектика“ и современите филозофски становишта на деконструкцијата, кои го проблематизираат статусот на стабилна и определена рационална концепција на односот меѓу книжевноста и нејзините репрезентативни механизми на правото, на правдата, на институциите и на човекот во нив и меѓу нив.

Книжевноста на Франц Кафка кај дел од критиката делумно, но и традиционално, е карактеризирана како интимна литература. Според објаснувањата

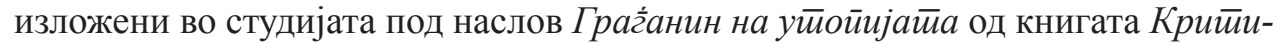
кийе на нашейо време и Кафка (Raboin 1973: 19), се говори со многу жестоки реакции против читателите или критичарите што во неговите пишувања ја забележувале врската меѓу неговата интима и напишаниот текст, па, оттука, неговото дело било определувано како интимистичко.

Втора квалификација со која овој автор е окарактеризиран на јавната сцена е дека тој е наклонет кон пишување литература исполнета со симболи, алегории или со апсурд. Со оглед на фактот дека овие одлики доминирале во контекстот во кој се реализира рецепцијата на делото на Кафка, особено во Франција, Делез и Гатари пристапуваат кон толкување од сосема различен агол. Имено, тие при интерпретацијата на неговото дело почнуваат да им даваат предност на текстовите на германските и на чешките критичари, кои се фокусирале врз позицијата на бирократијата, доведувајќк ја во врска со него- 
вото образование, а тоа е правото, и неговото вработување како бирократ во Социјалното осигурување, во синдикат на работниците за кои пишува бројни реферати. Со тоа, тие откриваат една сосема поинаква димензија во неговото дело и развиваат поинаков пристап: овие критичари укажуваат на неговата заинтересираност за политиката, во смисла на наклонетост кон социјалистичките и анархистичките движења (Deleuze \& Guattari 1975: 72).

Оваа димензија на делото на Франц Кафка не е забележана од страна на неговиот пријател Макс Брод, кој по неговата смрт уредува и издава голем дел од напишаните и зачувани дела. Покрај политичката компонента, во делото на Франц Кафка е карактеристичен уште една аспект врз кој се задржуваат Делез и Гатари, повикувајќ́ се на студиите на Вагенбах, под наслов Кафка,

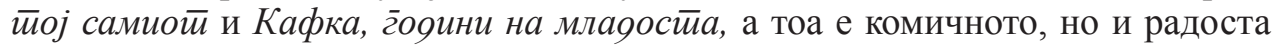
или, како што тие самите нагласуваат - во неговите книги станува збор за т.н. „радост на желбата“ (ibid., 76). Во врска со „политичката активност“, но и во врска со „радоста на желбата“, Делез и Гатари во делото на Кафка ги нагласуваат овие компоненти и тогаш кога животот е на граница со смртта, па и тогаш кога Кафка се занимава со „вината како со сопствен циркус“ (ibid., 76). Тоа е причината поради која станува многу проблематично толкувањето што се концентрира врз неврозата, анксиозноста, потоа аполитичноста и трагичноста определувана како особеност на егзистенцијата претставена во делото на Кафка. Тоа се елементи што го интерпретираат неговото дело премногу тесно, имено само како индивидуална, лична ситуација, проектирана во креацијата на книжевните репрезентации. Овие два аспекти, односот кон политиката, стварноста и односот кон радоста на желбата се потврдуваат и тогаш кога се коментираат начините на кои реагира публиката додека го чита првото поглавје на романот Процес, посмртно објавен во 1925 година. Во овој роман поглавјата се подредувани по редослед што е креиран од страна на Макс Брод. Генијалноста на Кафка се оцртува онаму каде што во исто време се провлеку-

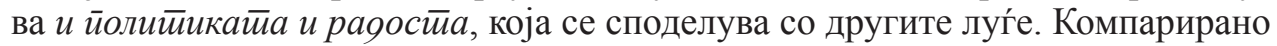
со делото на Ниче и Бекет, делото на Кафка, таму каде што се сведува на доживувања на страв или на трагични искуства, продуцира проблематично и многу искривено разбирањето на смислата и толкувањето и оди во насока на извлекување многу малку од множеството значења што Кафка настојува да ги претстави.

\section{2 Жанрови/преобразби/вина}

Творештвото на Кафка е познато преку неколку различни жанрови: писма чија одлика е остварувањето писмена врска со соговорничката, која секогаш останува незавршена, отворена; раскази во кои се појавуваат животни, а во

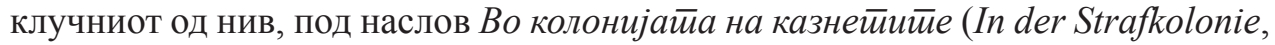
напишан 1914, ревидиран во 1915 и објавен во 1919), се појавува и машината за казнување. Се смета дека овој расказ на Кафка е споредлив со романот на францускиот писател Октав Мирбо, кој определени казнени постапки ги опишува во романот под наслов Граяина на измачувањайа (Le Jardin des supplices /Torture Garden, 1899/2003). Пишувањето на писмата за Кафка 
е начин на справување со яист̄анц̧айа на соговорникот, што му овозможува долги проекции и одложувања на идејата за средба, а со тоа и реализации на желбата за пишување. Паралелно со неа се јавува чувстивойо на вина, иако, првостепено, кај него тоа чувство на вина се поврзува со едиповското, семејно или брачно чувство на вина. Во расказот Пресyga (Das Urteil, 1912) избиваат во прв план прашањата за љубовта кон таткото, за способноста да се прифати брачната состојба и преиспитувањата околу тоа колку со откажувањето од венчавка и, воопшто, со откажувањето од реална, а не писмена и виртуелна врска со жена, тој е чудовиште. Темел на вината е, всушност, двојството што настанува во субјектот, кој во реалноста е весел и ослободен, сѐ додека постои допишувањето со вереницата, кон која се упатуваат писма во кои е содржана верзијата на субјектот на исказот. Субјектот на пишувањето во еден момент ја искажува својата тага поради прекинување на врската, меѓутоа нештата се усложнуваат токму кога се поставува прашање за правото сфатено како одговорност кон другиот, за што особено говорат Емануел Левинас и Жак Дерида. Во делот од животот на Кафка (за што говори во Дневницииее), кога пристигнува „пресудата во хотелот“, искажана од судот на семејството, пријателите и обвинителите, но и од жената со која не остварува ниту врска, а ниту брак, туку само писмени комуникации, според Левинас, односот кон другиот е правдата (Levinas 1979: 62). Левинас говори за т.н. „бесконечно право“, тој расправа за т.н. „еврејски хуманизам“, чија основа не е „правото на човекот“, туку „просторот на право на другиот“ (ibid., 17-18). Праведноста, според објаснувањата на Левинас, не е законот или легалитарноста, тоа не е изедначеност, правна распределба или дистрибуција на правдата, туку феномен во кој може да се регистрира апсолутна дисиметрија . Во расправата за Cилай на законой на Дерида, ниту една одлука не се сведува само на казнена одлука, таа мора да започне од состојбата на освестување и толкување на правилото сѐ до активности на практикување на мерењата или на пресметките. Треба да се договори односот меѓу она што може и она што не може да се измери или да се определи. Исто така, тој смета дека правилата не ги воспоставуваме во просторот и во времето каде што сме фрлени, туку од другата страна на моралот, на правото и на политиката. За да биде праведна една одлука во моментот во кој е донесена, таа треба да го доведува во прашање или да го поттикнува постојаното преиспитување на постојниот закон, според Дерида, но и да го реафирмира. Во врска со т.н. „бесконечна правда“, во контекст на деконструкцијата, Дерида настојува да ја објасни и вели дека таа добива димензии на „мистичност“ (Derrida 1992: 40).

Ако се вратиме на пишувањето на Франц Кафка, тогаш во Писмайа упатени до свршеничката Фелиција Бауер клучно значење добива чинот на судењето во форма на институционален, а не на индивидуален чин, кој го засега само интимното менување на ставовите или на релациите. Уште во почетокот на преписката со жената што ја има сретнато само еднаш, а со која се допишувал пет години, Кафка го пишува расказот Пресуяа, а потоа следува периодот на писма што пристигнуваат во огромен број, меѓутоа, на кои Фелиција не е во состојба да постигне редовно да испрати одговор. Реката писма е голема: започнува со раскинувањето на врската со Фелиција и вината станува централ- 
на тема и преокупација околу која започнува развивањето состави од слики, сцени и дијалози во расказите, но и во романите. Пресуяа е расказ што меѓу првите го тематизира проблемот на заокружена и доследна реализација на врската со Фелиција преку брак.

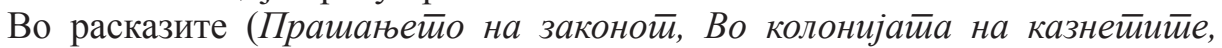
Сӣариой ерген Блумфеля, Мейаморфоза, Дувло, Пресуяа, Истиражувањаӣа на еуен иеес, Извешйај оо еяна акаяемија, Мелез и други), различно од писмата, човекот ја напушта својата територија на егзистенција, со што настанува детериторијализацијата и метаморфозата во животинскиот свет. Трансферот во територијата на животните не се случува со движење, со патување, бидејќи промената/метаморфозата може да се случува и во просторот на една соба, каде што не е неопходно да се има движење со изминување на долги растојанија за да му се даде значење на поимот яейерийоријализација, во смисла на промена на територијата или промена во просторна смисла. Расказите ги обединуваат реалниот или субјектот на искажувањето, говорителот и субјектот на исказот, имено, во тоа единство на субјективитети Кафка се приклонува кон нов обид за бегство или решение од институциите што го осудуваат, а тоа е животинскиот свет. Во животинската форма, клучна во поголем дел од неговите раскази, се минува прагот на хуманото, кое е деградирано и се случува излез кон новата димензија, која ги соединува двата субјекта што остваруваат бегство, но не успеваат да излезат од тој животински свет, тие во него се движат кружно и така ги менуваат позициите

Во романите на Кафка не се појавуваат животните како карактеристика, тука доминира машината и нејзиниот состав од елементи. Меѓу најизразитите примери на раскази со знаци за започнување роман е токму расказот во Ко-

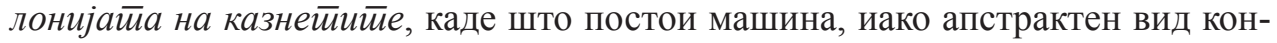
струкција, која на крајот од расказот се распаѓ, се раскршува. Во оваа фаза од сопствениот однос кон „машинскиот систем“ на општеството и функционирањето на желбите во него, Кафка може само да го опише изведувањето на казната, да ја наведе причината за казнување, да ја растури машината, а односот меѓу стариот командант и неговиот наследник на работното место во колонијата, која е активна на територијата на еден остров, завршува со враќање во конфликтната едиповска фаза на однос меѓу авторитетот на таткото и синот, на стариот командант и наследникот, кој освен што завршува со смрт, е последниот поставен на машината за казнување пред нејзиното конечно распаѓање. Повторното враќање во безизлезната состојба на животно е активирано со слика што во ревидираната верзија на расказот не е вклучена, имено, на крајот од приказната патникот/туѓинецот што е во посета на колонијата стои на четири нозе, како пес и, во таква позиција, ја напушта колонијата. Тоа значи дека излегувањето од фазата на детериторијализација во животно или од животинската фаза се остварува во големите композиции на романите.

Со луѓето како ликови во романите се разоткрива големата општествена слика на системот, на машината во која тие се само запчаници, меѓутоа се способни да дејствуваат во насока на примена на насилството и на нехуманите изразувања на желбите. Тоа е, според моќта на дејствувањето, најсилното 
подрачје во пишувањето на Кафка, каде што има проекција на општествениот систем во систем-машина на државата, на институциите во неа.

Во романот Проиес, токму поради самата општествено-политичка структура на овој вид дејство, се актуализира архивот од постапки што ги практикува Кафка кога стои пред определен суд поради прекинувањето на врската со Фелиција. Битно е да се нагласи дека во расказите се појавува животно (кое е резултат или настанува како реакција на општествено-политичкиот систем што врши опресија) или, со други зборови, хуманото метаморфозира во „другост“, додека во романот се проектира самиот систем на општествената реалност. Кафка не е автор што, според некои критичари, би се повлекувал во уметноста како во „кула од слонова коска“. Тој има сопствено ,дувло“, но во него ги повлекува сите економски, бирократски, политички, судски аспекти од кои ја пишува книгата. Кафка е правно-политички ангажиран автор, кој проговара за она што ќе се случува во светот во иднината. Одделени од трите клучни жанрови на искажување - писмата, расказите и романите, во делото на Кафка се вклучуваат низа куси форми, афоризми, но и религиозни, побожни параболи, како и дневниците. Ако побожните текстови, како и писмата, се поврзани со раскинувањето на свршувачката со Фелиција, по што се чувствува разочаран и тажен, дневниците се форма на писмо што соодветствува на едно големо формално разгранување во кое тој сосема се пронаоѓа себеси, а тоа е хоризонталното развлекување на ризомот. Тоа е причината поради која дневниците се во корелација со интерпретациите на писмата, на расказите и на романите, имено, тие се составни делови на книжевната машина на Кафка.

\section{3 Од вината до Законот}

Во составот од односи изведени од расказите, каков што е расказот Во коло-

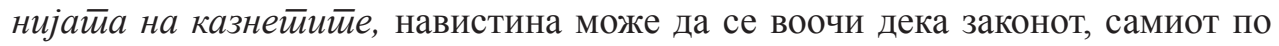
себе, е празен, тој нема содржина. Форма на потврдување на законот е донесувањето пресуда, а потврдувањето на пресудата се реализира со искажување и преку тоа со перформирање или извршување определена казна. Во расказот Во колонијайа на казнейийе никој не знае каков е законот, тој се спознава со тоа што пресудата се испишува на грбот на секој затвореник поставен на машината за казнување, а самата операција е, во исто време, извршување на казната. Во расказот За йрашањеӣо на законой, Делез и Гатари ги извлекуваат исказите во кои јасно се вели дека чувството на мачнина се појавува кога со човекот владеат законите што не ги познава, затоа што нивната одлика е таква што тие бараат нивната содржина да се чува како тајна.

Со пресвртот што го анализирал Кант, законот во јудео-христијанската епоха од развојот на историјата станува форма според која се определува она што го именуваме како Добро или како Исправно, додека, пак, во старата грчка епоха законот се засновувал на вечнойо яобро, кое му яавало сояржина или

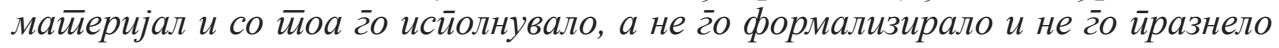
нег̄овойо ойреgелување како закон. Денес формалната процедура на испишување на законите во исто време значи однапред да се определи она што е Добро, а тоа суштински го формализира поимањето на законот како празна 
форма, како форма за исправно и добро дејствување условено од оној што го пишува законот. Тој нема намера да изгради слика на трансцендентен закон, тој настојува законот да го постави во позиција на слика според која функционира општествениот механизам кој „радосно“ е реконструиран во романот Процес. Законот во овој роман, според Делез и Гатари, функционира како надворешна решетка (Deleuze \& Guattari 1975: 111). Двајцата аналитичари се сомневаат во обликувањето на романот, според кое Кафка како завршница го поместил поглавјето во кое врз обвинетиот Јозеф К. се извршува казна, а како претходно поглавје го поставил она во кое се случува средбата на свештени-

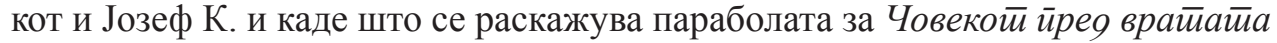
на законой.

Ако се прифати трансцендентноста на законот, тогаш мора да постои врска меѓу вината и пресудата, односно меѓу законот и луѓето врз кои законот има позитивно дејство. Вината, всушност, е една априорна состојба, која е поврзана со законот, односно со пресудата што се применува врз секој што греши; законот важи и за невиниот и за виновниот. Законот, според раскажаната пара-

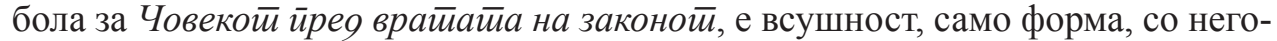
вото искажување се реализира пресудата. Законот и вината, но и внатрешните состојби, се движечки аспекти во ова дело.

Реалистичките и социјални аспекти се активни во делото на Кафка, иако тој претставува една иреална Америка во романот Америка (Der Verschollene, 1927), штрајк во Њујорк, кој е неубедливо прикажан, дава слика на Евреин во Прага, избор на судии што е бесмислен (во Процес), потоа мала партија која ѝ се покорува на партијата на аристократите (За иррашањейо за законой / Zur Frage der Gesetze, 1931) и слични слики во кои нема критики (на пример, ликот на Јозеф К. во романот Процес е на страната на оние што тепаат и што казнуваат). Тоа говори за поинаков вид критика, таа е насочена кон неговата внатрешност, па затоа нараторот (и авторот) настојува од позиција на општеството да ги изведе машинските системи преку системите на искажување, а со тоа да ги разложи. Тоа е постапка што е далеку поделотворна од каква било критика, сметаат Делез и Гатари:

Да се потсетиме на постојаната идеја на Кафка: дури и со осамениот механичар, книжевната машина на изразување е способна да ги претекне и да ги забрза настаните во услови кои, сакале или не, се однесуваат на цели заедници. Антилитеризам: 'Да се зграби светот` за да го натераме да се повлече, наместо од него да побегнеме или да го прегрнеме. (ibid., 109)

Наспроти незавршеноста на расказите или апстрактноста на критиките содржани во нив преку посочените машински делови на определена целина, во романите се појавува самата машина со делови што сосема се разглобуваат. Во самиот роман Процес (насловен со политичко-правен, па и научен термин), Кафка го актуализира феноменот на постапување во општествената реалност, меѓутоа ако таа подразбира во буквална смисла развој, промена, тогаш таква димензија во наведениот роман нема. Клучни прашања на овој роман се како функционира системот и кои функции ги извршува. 
Во сопствената расправа за делото на Кафка, Делез и Гатари упатуваат на тоа дека онаму каде што постои закон, всушност, постои само желба, бидејќи правдата не е закон, туку само желба. Казната е желба на оној што казнува и оној што е казнет. Исто така, претставниците на правдата, сметаат двајцата автори, не ја истражуваат неправдата, тие се привлечени и мобилизирани токму од злосторствата. Претставувањето на правдата е невозможно, таа е само желба. Станува збор за слика во расказот За йрашањетй на законой, според која законот постои во иманенцијата на машинското обликување, кое во себе ја антиципира желбата за правда. Таа е иманентен процес на желбата. Со правдата се означува континуумот од желба по однос на чие остварување границите се постојано подвижни. За вистинско ослободување кај Кафка не може да стане збор, постои континуитет од пресвртувања, така што прашањето за невиност или вина потпаѓа под привидно ослободување, во кое се инкорпорирани два периода што се во дисконтинуитет. Невиноста и вината се две бесконечни состојби, тие постојано се одолговлекуваат и се анализираат, бидејќи во самите ситуации нема „случка, процес“, тие се само слики.

Од друга страна, правдата и правото во Бенјаминовата концепција се доведуваат во врска со силата, па тој во својот есеј под наслов Прилог кон кри$\bar{u} и к а \bar{u} а$ на силай $а$ укажува на вмешувањето на силата по однос на моралните односи. Правните цели на поединецот се спротивставени на природните цели, првите инсистираат на целта, а природното право инсистира на средствата. Правните цели, смета Бенјамин, имаат тенденција да бидат остварени без сила, а тоа значи со самото впишување/изгласување на законот, тие се активни. Правните цели во однос на нивното важење за поединецот значат дека се тежнее тие да се постигнат без сила. Правните цели настојуваат да се наметнат и во оние подрачја каде што на природните сили им е дадено редовно пошироко подрачје на дејство. Такво е образованието, имено, онаму каде има казнувања се тежнее тие со правна сила да бидат ограничени. Секоја природна цел на поединецот може да се судри со правните цели, ако таа се спроведува насилно. Правото ја посматра силата во рацете на поединецот како средство да се поткопа правото. Позитивното право разликува сили што санкционираат, но и такви што не санкционираат. Ако позитивното право ја легитимира примената на силата, тогаш она што се преиспитува е вредноста на таа сила.

Намерата правото да манипулира со силата не се состои само во заштитата на неговите цели, туку во заштитата на самото постоење на правото. Зошто силата станува опасна за правото, зошто тоа се плаши од неа? Работничката класа единствено има право на сила и тоа преку штрајк. Според работниците, правото на штрајк е примена на сила која е во функција на остварување на целите, а тоа е стекнување на позиција на моќ. Тенденцијата на модерното право се состои во тоа што секоја сила што се однесува на заштита на поединецот и која е ориентирана кон природните цели треба да се третира како правен субјект. Кога се работи за злосторник што направил големи злосторства, тогаш силата му се заканува дека ќе воспостави ново право. Таквата сила што менува може да предизвика страв, затоа што поттикнува на водење војна или кревање штрајк. Милитаризмот е општа примена на силата во име на држав- 
ните цели. Тоа не е проста примена на сила за природни цели. Тоа е примена на сила за правни цели. Критиката на воената сила треба да се совпаѓа со критиката на власта, извршна или правна. Проблемот на правната закана се состои во тоа што таа се открива како судбина, на пример - смртната казна. Позитивното право е изложено на критика токму поради смртната казна. Критичарите сметаат дека со смртната казна не се напаѓa само една мерка, туку самото право. Од друга страна, пак, полицијата е институција на сила што дејствува во насока на извршување на правните уредби, но и моќ што го определува применувањето на правото од тие уредби. Отсуството на сила е карактеристика на ситуациите каде што луѓето умеат да се разберат со јазикот. Праведноста не се сведува на правото и покрај тоа што тие две сфери не се неповрзани (Benjamin 1974: 54-79).

\section{4 Законот и јазикот}

Законот (правото), се артикулира низ комплекс правила што го уредуваат политичкото живеење на луѓето, а тие правила се отелотворуваат низ јазикот. Но, амбивалентната суштина на законот едновремено ја открива и својата друга димензија: очуденоста. Ова својство на законот подразбира дека тој секогаш веќе дејствува и во полето на нелингвистичкото, односно на неискажливото, кое, според Агамбен, повторно е ,инвенција на самата реч и само во неа може да зачнеме слична замисла (за нелингвистичко). И, од нелингвистичкото, јазикот секогаш се враќа“" (Agamben 2016: 38)

Кафка во голем дел од својот опус, во еден аспект, се обидува да ја долови токму таа суштина на законот: неговата реификација во однос на субјектот за кој е наменет упатува токму на неговата неискажливост, недофатливост, неможноста да се досегне до неговата суштина. Стилистичкиот печат што му го дава Кафка на романот Процес, нелингвистичкото што го изразува низ јазикот, постојаната отвореност на романот кон низа интерпретации во однос на она што подразбира закон и систем е, всушност, отпечаток на обидот да се расветли едно од многукатните лица на законот. Преку начинот на кој е конструирана нарацијата, Кафка го осветлува она што, всушност, не може да се осветли, односно ,нелингвистичкото, премолчано од речта (во неговиот роман) е совршено искажливо“ (ibid., 38, приспособен превод И.Т.)

Релацијата меѓу јазикот и законот Агамбен ја воспоставува, пред сѐ, во толкувањето на Во казненайа колонија. Направата за измачување, вели Агамбен, измислена од поранешниот командант на Колонијата, всушност, е јазикот. А, самата направа е инструмент за казнување и за спроведување на правдата. Она што, според Агамбен, осудениот најпосле го сфаќа во шестиот изминат час е смислата на јазикот. Бидејќи луѓето го живеат животот како суштества што говорат, без притоа да ја разберат неговата суштина. А, разбирањето на неговата суштина, не преку постапката на логичкото расудување, туку во подлабока смисла, може да се оствари само преку болката (која првично е телесна болка), односно, доколку јазикот се претвори во казна - и пресудата (која го подразбира и самиот процес на донесување суд) и јазикот, својата основа ја имаат во постапката на логичкото расудување. Но, за човекот да ја разбере 
самата смисла на животот, и пресудата (giudizio) и јазикот, во мигот кога тие проговоруваат нужно се претвораат во кривична пресуда, односно во казна.

Дополнително, во насока на релацијата меѓу јазикот и законот, која Агамбен ја чита кај Кафка, би требало да се напоменат уште неколку фрагменти. Имено, офицерот и истражувачот меѓусебно зборуваат на француски, јазик што не го разбираат ниту осудениот ниту војникот задолжен да ги држи ланците од машината, со што остануваат изолирани од главниот дискурсивен тек и во нив го истакнува нагонското. Оттука, Кафка на просторот на казнената колонија му дава клаустрофобичен печат, простор во кој протагонистите се поставени на работ меѓу човекот и животното. Тежи во приказната напорот на осудениот да разбере што му се случува, а конечно, и да го разбере оној задолжен да ја спроведе правдата:

(...) офицерот зборуваше на француски и, се разбира, ниту војникот ниту осудениот не го разбираа тој јазик. Уште повпечатливо беше тоа што осудениот се напрегаше да ги следи објаснувањата на офицерот. Со невообичаена упорност постојано го вртеше погледот онаму каде што покажуваше офицерот, а кога овој беше прекинат од истражувачот со прашање, и самиот, како и офицерот, го погледна истражувачот“ (Kafka 2006: 267, превод И.Т.).

Во мигот кога самиот офицер легнува под железната брана и на направата наместо командата: „Почитувај го својот претпоставен“, ѝ ја задава командата: „Биди праведен“, таа од направа за измачување се претвора во машина за убивање. Во оваа смисла, Агамбен дава две можни толкувања на приказната. Според едното, офицерот во функција на судија го прекршил начелото „биди праведен“" и, оттаму, мора да биде казнет, а заедно со него и направата што е соучесник во нанесувањето неправда.

Пред да дадеме преглед на второто толкување на Агамбен, би направиле кус екскурс. Всушност, во расказот полето на вината не е јасно определено. Дотаму што Кафка вината на осуденикот не ја доведува до прашање: тој е а приори виновен.

Ваква е работата. Бев назначен судија овде, во оваа казнена колонија, и покрај тоа што сум млад, бидејќи соработував и со стариот командант за сите кривични прашања и совршено ја познавам оваа машина. Принципот според кој одлучувам е следниов: вината никогаш не се доведува во прашање. Други судови не можат да го следат овој принцип, бидејќи се составени од повеќе луѓe, а згора на тоа, над себе имаат повисоки инстанции. (...) (ibid., 270)

Во казнената колонија командантот дејствува по обвинение за наводна повреда на законот, а тоа се чини доволно за веднаш се активира казнениот механизам на машината. Во казнената колонија има исклучив казнен систем; таа претставува своевидна јуридичка празнина, во која процесите на правниот

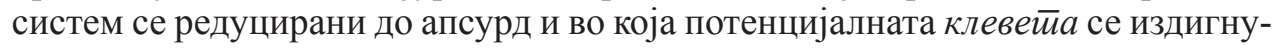
ва на ниво на моќна алатка за ставање во дејство на таквиот систем.

Еден капетан официјално утрово ме информираше дека овој човек, кој му бил доделен како ординарец, и кој спие пред неговата врата, спиел за вре- 
ме на својата служба. (...) Таква е фактичката состојба. Капетанот беше кај мене пред еден час, јас напишав извештај и веднаш донесов пресуда. Потоа го оковав човекот во синџири. Многу едноставно. Ако претходно го повикав човекот на распит, само ќе настанеше збрка. Ќе лажеше и, ако ми успееше да ги побијам неговите лаги, ќе ги заменеше со други и така натаму. (ibid., 271)

Напишан во 1914 година, Кафка со овој расказ, од една страна, се чини како да ги навестува големите тоталитарни режими што ќе земат свој замав само неколку децении подоцна, но од друга страна, посочува на еден сегмент од природата на односот меѓу субјектот и законот, кој е постојано потенцијално присутен и во услови кога јуридичкиот систем го зазема својот регууларен тек. Обвинението, исто како и во романот Процес, е јуридичка категорија par excellence, без која - како што тврди Агамбен, поаѓајќи од грчкото значење на зборот kategoria = обвинение - целата конструкција на законот би се распаднала и, всушност, тоа е суштината на бидувањето внатре во законот. Субјектот влегува во активна релација со Законот во мигот кога обвинението ќе стане активно; сѐ до тој момент, тој однос е задржан во сферата на потенцијалноста.

Второто Агамбеново толкување вели дека начелото „биди праведен“ не се однесува на наредбата што тој ја прекршува, туку е упатство за самоуништување на машината, а и самиот офицер го навестува таквиот исход во мигот кога ѝ ја задава наредбата. „Крајната смисла на јазикот (...) е наредбата 'биди праведен'; сепак, токму смислата на таа наредба е она што машината на јазикот апсолутно не е во состојба да ни ја објасни. Односно, може да го стори тоа само ако престане да ја врши својата казнена функција, само ако се распарчи и ако од казнувач стане убиец.“ (Agamben 1986: 40)

Сепак, би било значајно да се дополни дека јазикот не само што не е во состојба да го објасни туку и наредбата „биди праведен“ законот/јазикот го доведува до состојба на имобилизација поради апсолутната неможност таквата наредба да биде спроведена. „Биди праведен“ е прагот кон кој јазикот/законот секогаш ќе конвергира, но - со оглед на тоа што јазикот не може да објасни, а оттаму и законот не може да принуди негово спроведување - секогаш одново ќе го доживуваат својот пораз.

\section{5 (Невоз)Можна субверзија?}

Прашањето на клеветата Агамбен го гледа и во романот Проиес. Според него, К., всушност, не е знак за Кафка, како што Макс Брод погрешно толкувал, туку за клевета (lat. kalumnia), која во римското право била сериозна закана за спроведувањето на правдата, а лажниот обвинител бил казнуван со жигосување на буквата К на неговото чело. Токму клеветата Агамбен смета дека е клучот во целиот роман: „Обвинетиот, со оглед на тоа што се клевети себеси, совршено е свесен дека е невин, но, со оглед на тоа што се обвинува себеси, тој е подеднакво свесен дека е виновен за клевета. (...) Тоа е кафкијанска ситуација par excellence. Но, зошто К - и зошто секој човек - се клевети, лажно се обвинува себеси?““ (Agamben 2018: 14)

Кафка, на малку поинаков начин, повторно ги доведува во прашање двата постулати на правото: вината и обвинението. Според Агамбен, Јозеф К. преку 
себеклеветењето прави субверзивен обид да се избори со законот и со неговата суверена моќ, да го направи иноперативен во однос на него:

Од една страна, К беше убеден во добрите намери на свештеникот, (...) не беше невозможно тој да добие од него одлучен и прифатлив совет што нема да му посочи на кој начин може да изврши влијание врз процесот, туку како би можел да избие надвор од процесот, како би можел да го заобиколи, како би можел да живее надвор од процесот. (Kafka 2009: 153, превод И.Т.)

Бидејќи, она што низ романот станува јасно, особено преку репликата на свештеникот, е дека „пресудата не доаѓа одеднаш, самиот процес постепено се претвора во пресуда“ (ibid., 152). Се чини дека политичкиот субјект $a$ priori ce наоѓa во орбитата на законот, а со тоа и на процесот и - без оглед дали станува збор за морален или судски процес - тоа претставува суштинско обележје на неговото политичко живеење. Во основата на параболата йреg

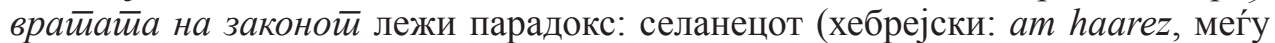
другото, и со значење на необразован човек) не може да влезе, затоа што таа врата е веќе ширум отворена само за него, го опфаќа без тој да биде свесен. Единствено со неговата смрт се затвора вратата и тој, сепак, останува надвор од дејството на законот. Но, самото оневозможување селанецот да влезе во законо $\bar{u}$, самото негово бидување надвор од законот, сепак, е еден аспект на дејствување на законот. За разлика од селанецот, Јозеф К. е внатре во законот и неговата цел е да го направи иноперативен. Оттука, според Агамбен, „човек[от] ја разбира суптилноста на себеклеветењето како стратегија што цели кон тоа да го направи иноперативно обвинението, импликацијата која законот му ја упатува на битието“. (Agamben 2018: 16)

Можен ли е субверзивен однос кон законот?

Во едно од бројните толкувања на параболата, кои свештеникот му ги изнесува на К., се вели дека, всушност, односите меѓу чуварот и селанецот се поинакви отколку што изгледа: чуварот е тој што е подреден и неслободен, бидејќи е врзан во служба на законот, а селанецот е слободен, бидејќи може да оди каде сака, единствено не смее да влезе во законот (барем не во моментот кога тој бара, неговиот влез останува можен во потенцијално идно време). Старецот умира слободен, надвор од опфатот на законот, додека, пак, Јозеф К. умира, како што ќе изјави и самиот со своите последни зборови, „како куче“. Токму во тоа се претвора човекот штом законот за него ќе стане оперативен: влегува во лиминалниот праг меѓу човечкото и анималното, за што стануваше збор погоре во текстот.

Сепак, погрешно е доколку од оваа комплексна парабола, чие значење постојано се искрадува, тежнееме да извлечеме толкување, зашто Кафка и самиот се чини свесен дека и тој никогаш не успева да допре до самата срж на законот и на системот, кој како Минотауров лавиринт се завива околу него. При егзегезата на параболата, која се одвива меѓу Јозеф К. и свештеникот, и самиот К. чувствува дека, колку повеќе се обидува да разбере толку повеќе изворната, напишана приказна ја губи својата форма.

Оттаму, неизбежен е (a, се чини и единствен) фактот дека опусот на Кафка и понатаму останува податлив за бројни интерпретации. Дотаму што се чини 
како да го опфатил во целост човештвото: неговото минато, сегашност и иднина. Зашто законот, како суверена моќ, е постојан и аморфен, неприкосновен и повредлив. Во таа насока е и искажувањето на свештеникот: „Она што е напишано е непроменливо, а толкувањата честопати се израз на очај поради таквата состојба“" (Kafka 2009: 157). А, дали законот, како што вели свештеникот, треба однапред да се прифати како нужен, и покрај тоа што можеби не се заснова на вистинитост, тоа прашање - и покрај тоа што наидува на негодување од страна на Јозеф К. - се чини дека Кафка за навек го остава отворено.

И, најпосле, единствената константа во односот меѓу законот (правото) и субјектот е токму „очуденоста“ на самиот закон за која стануваше збор на почетокот од текстот. Таквата реификација на законот по однос на субјектот ја навестува и затворскиот свештеник, кога вели: „Судот не сака ништо од тебе. Те прифаќа кога доаѓаш и те пушта кога заминуваш.“ (ibid., 160)

\section{6 Контекстуална рефлексија}

Останува фактот дека е Кафка еден од големите автори во XX век, кој најкохерентно одговорил на задачата да се разреши, во еден релативно тесен временски сегмент, конфликтот меѓу стариот свет во распаѓање и новиот поредок, кој е на патот на воспоставување. Соочен со човековата неможност да ги присвои своите сопствени историски претпоставки, тој се обидел токму таа неможност да ја трансформира, претворајќи ја во почва на која човекот (можеби) би можел да се обнови.

Постои една белешка во дневниците на Кафка каде што оваа неможност на човекот да си го поврати својот простор во тензијата меѓу минатото и иднината се искажува прецизно со една слика, слика во која убиствено едноставно се прикажуваат патници во воз. Возот наидува на несреќа во еден тунел, и тоа на место каде што светлината од почетокот веќе не може да се види, а светлината на крајот од тунелот е толку мала што погледот постојано мора трескавично да ја бара... Но, таа трепери и постепено се губи, така што патниците, во напрегнувањето на погледот, веќе не се сигурни дали се работи за почеток или за крај на тунелот.

Општото знаење за Кафка е такво што него лесно го сместуваат меѓу песимистичките книжевни филозофии или во филозофијата на апсурдот. Но, како и оваа слика од неговите белешки, која е само навидум едноставно песимистичка, така и неговото творештво само навидум ја изразува безнадежноста на индивидуата во историското постоење. Кафка, како Евреин што живеел во Прага и пишувал на германски јазик, како двоен и троен изгнаник, знаел многу повеќе од другите и ја пресвртел идеалната слика за ангелот на историјата и за линеарното време на човековиот прогрес. Така, тој веќе не ја гледа идејата за историјата како бескрајно расклопување по должината на линеарното време кое се стреми кон некоја цел, туку како една парадоксална слика за состојбата на историјата во која фундаменталниот настан на човековата состојба постојано се случува и ја прекинува линеарноста.

Зошто е Кафка актуелен и денес? Одговорот на ова прашање лежи сигурно во огромната моќ на обопштување што ја поседува неговото уметничко дело, 
така што гротескната актуелност со сите нејзини детали веројатно се должи токму на неговиот книжевен одговор за местото на човекот во (историските) процеси, во поредокот, во законот на времето и општеството.

Исклучително е битен контекстот во кој Кафка го развива својот „епски пат“, кој го отсликува бегството на човекот во нечовечкото. Тој контекст секако ги опфаќа „колективните општествени машини“, како што ги нарекуваат Делез и Гатари, кои ја операционализираат масивната детериторијализација на човекот. Кафка секако ја чувствувал во сите пори акцелерацијата, брзината на времето, но и брзината на сегментацијата на светот: Америка, која бргу се движела кон тврдиот капитализам; Австро-Унгарија, која е во процес на сопствено расчленување и која ја одбележуваат, од една страна, центипеталната сила на „царското и кралското“ и, од друга, центрифугалната сила на малите нации во раѓање; Германија, која од пепелот и вината на Првата светска војна се подига во подготвување на нацизмот; руската револуција, која со голема брзина почнува да ја пораѓа новата застрашувачка бирократија. Во тој систем од растечки, различно формулирани, „дијаболични формации“, Кафка, секако, станува политички автор, но, како што вели Паскал Казанова, на профетски начин.

Во своите „Размислувања за гревот, страдањето, надежта и вистинскиот пат“, кои припаѓаат во неговите повеќе филозофски дневнички записи од периодот меѓу 1917 и 1919 година, меѓу другото, тој ги забележува и следниве редови:

102. Сите страдања околу нас мораме и ние да ги отстрадаме. Сите ние немаме исто тело, но имаме исто растење и тоа не спроведува низ сите болки, сеедно дали во овој или во оној облик. Како што детето се развива низ сите животни степени сѐ до староста и смртта ( $\mathrm{a}$, тој степен, во основа, му се чини недостижен на копнежот или на стравот на претходниот степен), така и ние се развиваме (поврзани со човештвото не помалку длабоко отколку што сме поврзани со самите себеси) низ сите страдања на овој свет. За волја на вистината, во овие рамки нема место, но нема место ни за страв од страдањата ниту, пак, за толкувањето на страдањето како заслуга.

89. Човекот има слободна волја, и тоа тројно: Прво, тој бил слободен, кога го сакал овој живот; сега тоа, навистина, веќе не може да го одрече, затоа што веќе не е оној што тоа го сакал, освен во онаа мера во која ја остварува својата некогашна волја, со оглед на тоа што живее. Второ, слободен е затоа што може да го избира начинот на кој оди и го избира патот во овој живот. Трето, слободен е затоа што, како оној што еднаш повторно ќе постои, има волја во сите услови да оди низ животот и на тој начин да дојде до себеси и тоа по еден пат кој, додуша, може да се одбере, но, во секој случај, толку е лавиринтски што не остава недопрено ниту едно местенце во овој живот.

Тоа е тројноста на слободната волја, но оваа тројност, бидејќи е истовремена, е и едно, и во основа е толку едно што не остава никакво место ни за волја, ни за слобода, ни за неслобода.

40. Само нашето сфаќање на времето ни дозволува да зборуваме за Последниот суд или за Конечниот суд; а тоа е, во суштина, само вонреден суд. (Kafka 1984a: 367-380) 
Кон крајот на педесеттите години на XX век Теодор Адорно ја признава тегобноста на навраќањето кон Кафка:

Кафкината омиленост, угодноста поради неугодното, кое понижувачки го сведува на информативен инструмент, било за вечната, било за денешната ситуација на човекот, и со брзи заклучоци го трга скандалот на кој почива делото, предизвикува неволност да се учествува во тоа и на тековните мислења да им се додава едно свое, макар и спротивно. Но, и покрај тоа, Адорно инсистира на издвојување на формулациите на несопирливито насилство, кое во фикциите на Кафка секогаш го вршат „фигурите од субалтернацијата“: подофицери, капитуланти, портири, ситни службеници бирократи (Adorno 1985: 124, превод М.Б.).

Неслучајно истото фундаментално насилство што се преточува во (правен?) систем веројатно го имал на ум писателот Клаус Ман, несреќниот син на големиот татко Томас Ман, кој инсистирал на сличноста на Кафкиното Царство со Третиот Рајх. Тој вид на пекол, според Адорно, само го подотворило доцното граѓанство. Но, ужасот и големината на Кафка не е само во ониричното предвидување на судбината на Евреинот, едноставно затоа што Евреинот стои на почетокот на колоната во која, во современиот свет, се движат сите луѓе, односно самиот човек. „Во фашистичките концентрациони логори“, вели Адорно, била

збришана демаркациската линија помеѓу животот и смртта. Тие создале меѓусостојба, живи костури и луѓе што скапуваат, жртви што и самоубиството ги изневерило, смеа на сатаната над надежта и укинување на смртта. Како во Кафкините превртени епови тука пропаѓал од себе до крајот проживеаниот живот, мерката на искуствот (ibid., 125).

Конечно, ако барем во некоја мера може да се објасни големината на Кафка денес, таа мера веројатно лежи во опсегот на неговото темелно разобличување на фундаменталното и востановувачко насилство, кое се протега од точката на арбитрарното семејство, па сѐ до правниот и општествен систем. 


\section{Библиографија}

Adorno, Th. (1985). Filozofsko-sociološki eseji o književnosti. Zagreb: Školska knjiga. Agamben, G. (1999). The Man without Content. Stanford: Stanford University Press.

Agamben, G. (2018). K. in Clemens J, Heron N. and Murray A. (eds) The Work of Giorgio Agamben: Law, Literature, Life. Edinburgh University Press.

Agamben, G. (2016). Quattro glosse a Kafka. Rivista di Estetica 22 (1986): 37-44. Date Accessed 20 Mar., 2018.

Benjamin, W. (1974). Eseji. Beograd: Nolit.

Casanova, P. (1999). La rèpublique mondiale des lettres, Paris: Seuil.

Deleuze, G., Guattari, F. (1975). Kafka, pour une littérature mineure. Paris: Minuit.

Derrida, J. (1992). Force of Law: The Mystical Foundation of Authority in Drucilla C. and Michael R. (eds), Deconstruction and the Possibility of Justice. New York: Routledge.

Kafka, F. (1984). Dnevnici 1910-1913. Beograd: Nolit.

Kafka, F. (1984a). Dnevnici 1914-1923. Beograd: Nolit.

Kafka, F. (2006). Tutti I racconti. Milano: Oscar Mondadori.

Kafka, F. (2009) The Trial. Oxford: Oxford University Press.

Levinas, E. (1979). Totality and Infinity. The Hague, Boston/London: Martinus Nijhoff Publishers.

Mirbeau, Octave. (1899/2003). Le Jardin des Supplices. Paris: Éditions du Boucher.

Moran, B., and Salzani, C. (eds). (2013). Philosophy and Kafka. Lanham: Lexington Books.

Raboin, C. (1973). Les Critiques de notre temps et Kafka. Paris: Freres Garnier. 
